\title{
PLASMA MODIFICATION OF MICROFIBERS - APPLICATION TO LIGHTWEIGHT CEMENT COMPOSITE CONTAINING RECYCLED CONCRETE
}

\author{
Jakub Ďureje ${ }^{a, *}, Z_{\text {DenĚK }}$ ProšeK $^{a}$, JAn TRejbal $^{a}$, PAVel TesáreK $^{a}$, \\ ŠTĚPÁN POTOCKÝ ${ }^{b}$ \\ ${ }^{a}$ Czech Technical University in Prague, Faculty of Civil Engineering, Department of Mechanics, Thákurova 7, \\ 16629 Prague 6, Czech Republic \\ ${ }^{b}$ Academy of Sciences of the Czech Republic, Institute of Physics, Cukrovarnická 10, 16253 Prague 6, Czech \\ Republic \\ * corresponding author: jakub.dureje@fsv.cvut.cz
}

\begin{abstract}
The article deals with the optimalization of composition for reinforced lightweight cement composite containing micronized recycled concrete, which will be used to produce masonry blocks. The composite material is reinforced with polypropylene microfibers. To increase the cohesion between the fibers and the cementitious matrix, the optimal modification using oxygen plasma was chosen. Furthermore, a suitable foaming agent was chosen to lighten the cement matrix. A suitable ratio of cement and micronized recycled concrete was determined. Finally, a cement composite was made from the optimized components. The mechanical properties of this composite were tested. The resulting mechanical properties of the lightweight samples were compared with the non-light samples.
\end{abstract}

KEYWORDS: Lightweight cement composite, micronized recycled concrete, oxygen plasma, plasma treatment.

\section{INTRODUCTION}

One of the most important properties of cement composites is the cohesion of the fiber with the matrix. Cohesion depends on a matrix in close proximity to the fiber, on the Interfacial Transition Zone $[1,2]$. Chemical and mechanical modifications of fiber surfaces are used to increase the cohesion between the fibers and the matrix. Manufacturers of fibers most often apply mixtures of various chemicals to their fibers in order to increase the cohesion of the fibers with the cement matrix. However, chemical treatments are non-ecological [3]. Using plasma, it is possible to modify the surface both mechanically and chemically. The process of plasma modification depends on many parameters, such as the time of modification, the working gas, the input power, etc. Plasma modifies only the surface of fibers, therefore occurs to almost negligible loss of mechanical properties of the fiber itself. In addition, the process of plasma modification is more environmentally friendly than conventional methods of chemical modification $[4,5]$.

The most common use of recycled concrete (more than 90\%) is in its unbound form as a backfill under the road. Another possibility is its use in bonded form as a substitute for aggregates in cementitious composite materials. With a suitable production process and composition, cementitious composites containing recycled concrete can achieve similar mechanical properties as same composites without recycled concrete. For the production of composite material, micromilled recycled concrete was chosen, which was made from the finest fractions of recycled concrete, which is currently considered waste [6-8].

To lighten the cement composite, it is necessary to choose a foaming agent that has sufficient stability and frothiness after mixing with water and foaming. High foaming causes the formation of many air cavities in the material. The stability of the foam must ensure that the foam transfers load from the cement mixture until the material has sufficient load-bearing capacity to transfer its own weight. Stability affects the resulting mechanical strength [9].

\section{MATERIALS AND SAMPLES}

Portland cement CEM I 42.5 R from Českomoravský cement, a.s. (Radotín) was used. Micronized recycled concrete was made from drainage gutters. To produce micronized recyclate was used waste recycled concrete with a fraction of $0 / 16 \mathrm{~mm}$, which was subsequently ground by high-speed mills. The grain size of the resulting micronized recyclate was less than $0.25 \mathrm{~mm}$. A suitable foaming agent was selected not only from the foaming agents intended for concrete, but also the foaming agents intended for industrial cleaning were tested. Polypropylene microfibers with a diameter between 18-32 $\mu \mathrm{m}$ and a length about 12 $\mathrm{mm}$ were chosen to reinforce the samples. Plasma modification by oxygen plasma under reduced pressure was performed using a Tesla VT 214 device. Microfibers were inserted into the chamber of the device 

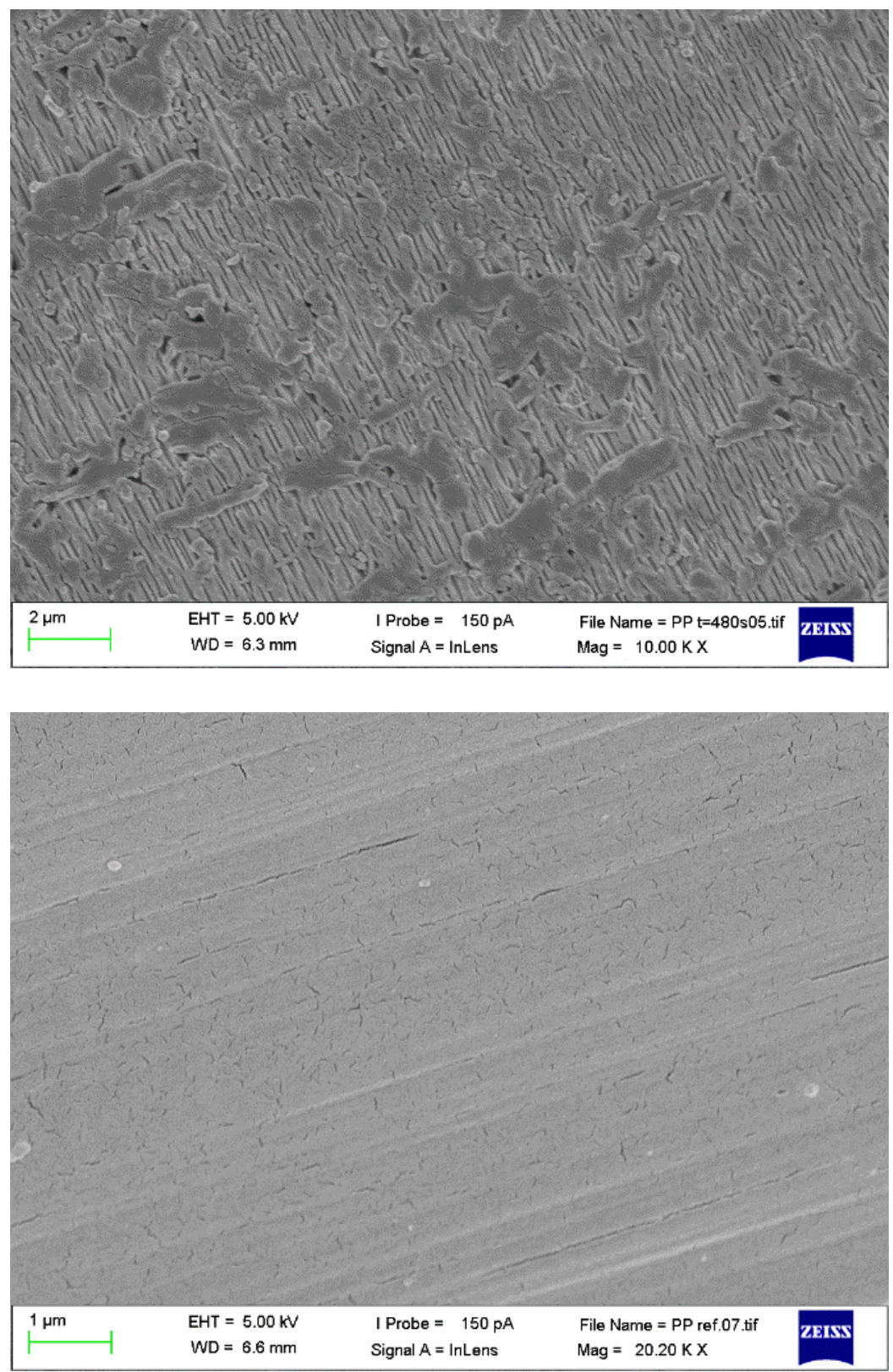

FiguRE 1. Surface of the polypropylene microfiber, left - reference fiber, right - fiber after treatment by oxygen plasma for 480 seconds.

and then air was sucked out of the chamber, after that the pressure in the chamber was only about $22 \mathrm{~Pa}$.

Subsequently, oxygen was filled into the chamber, the pressure in the chamber increased to $60 \mathrm{~Pa}$. Subsequently, the plasma modification process was performed for 60 or 480 seconds. After completion of the plasma modification process, the chamber was filled with air to atmospheric pressure and then the fibers were removed. Images of the microfiber surface before and after plasma modification process are shown in Figure 1. To determine the stability of the modifications, part of the fibers were left in an environment at a temperature of about $20^{\circ} \mathrm{C}$ and a relative humidity of $50 \%$ for 5 days (PP 480 air) before application into the cement matrix, the other fibers were applied into the cement matrix immediately after the modifica- tion. Selected surface modifications of the fibers that were subsequently used to produce reinforced samples are listed in Table 1.

\begin{tabular}{ccc}
\hline Sample & $\begin{array}{c}\text { Modification } \\
\text { time }[\mathrm{s}]\end{array}$ & $\begin{array}{c}\text { Storage } \\
\text { time }[\text { days }]\end{array}$ \\
\hline PP ref & 0 & 0 \\
PP 60 & 60 & 0 \\
PP 480 & 480 & 0 \\
PP 480 air & 480 & 5 \\
\hline
\end{tabular}

TABLE 1. Selected surface modification of polypropylene microfibers by oxygen plasma.

The composition of the lightweight samples without microfibers reinforcement is in Table 2. The com- 


\begin{tabular}{cccccc}
\hline Set & $\begin{array}{c}\text { Cement } \\
{[\mathrm{g}]}\end{array}$ & $\begin{array}{c}\text { Recyclate } \\
{[\mathrm{g}]}\end{array}$ & $\begin{array}{c}\text { Water } \\
{[\mathrm{ml}]}\end{array}$ & $\begin{array}{c}\mathrm{W} /(\mathrm{C}+\mathrm{R}) \\
{[-]}\end{array}$ & $\begin{array}{c}\text { Foaming agent } \\
{[\mathrm{ml}]}\end{array}$ \\
\hline $\mathrm{C}$ & 1500 & 0 & 480 & 0.32 & 0 \\
$\mathrm{CR}$ & 750 & 750 & 480 & 0.32 & 0 \\
$\mathrm{CS} 2$ & 1500 & 0 & 480 & 0.32 & 1.5 \\
$\mathrm{CRS} 2$ & 750 & 750 & 480 & 0.32 & 1.5 \\
$\mathrm{CS} 4$ & 1500 & 0 & 480 & 0.32 & 3.0 \\
CRS4 & 750 & 750 & 480 & 0.32 & 3.0 \\
\hline
\end{tabular}

TABLE 2. Composition of the lightweight samples without microfibers reinforcement.

\begin{tabular}{ccccccccc}
\hline Set & $\begin{array}{c}\text { Cement } \\
{[\mathrm{g}]}\end{array}$ & $\begin{array}{c}\text { Recyclate } \\
{[\mathrm{g}]}\end{array}$ & $\begin{array}{c}\text { Water } \\
{[\mathrm{ml}]}\end{array}$ & $\begin{array}{c}\mathrm{W} /(\mathrm{C}+\mathrm{R}) \\
{[-]}\end{array}$ & $\begin{array}{c}\text { Foaming agent } \\
{[\mathrm{ml}]}\end{array}$ & $\begin{array}{c}\text { Fibers } \\
{[\mathrm{g}]}\end{array}$ & $\begin{array}{c}\text { Fibers } \\
{\left[\mathrm{kg} . \mathrm{m}^{-3}\right]}\end{array}$ & $\begin{array}{c}\text { Plasma } \\
\text { modification }\end{array}$ \\
\hline $\mathrm{CRF}$ & 750 & 750 & 480 & 0.32 & 0 & 0.75 & $\approx 1$ & no \\
$\mathrm{CRFP}$ & 750 & 750 & 480 & 0.32 & 0 & 0.75 & $\approx 1$ & yes \\
$\mathrm{CRS} 2 \mathrm{~F}$ & 750 & 750 & 480 & 0.32 & 1.5 & 1.43 & $\approx 1$ & no \\
$\mathrm{CRS} 2 \mathrm{FP}$ & 750 & 750 & 480 & 0.32 & 1.5 & 1.43 & $\approx 1$ & yes \\
CRS4F & 750 & 750 & 480 & 0.32 & 3.0 & 1.875 & $\approx 1$ & no \\
CRS4FP & 750 & 750 & 480 & 0.32 & 3.0 & 1.875 & $\approx 1$ & yes \\
\hline
\end{tabular}

TABLE 3. Composition of lightweight samples reinforced by plasma treated microfibers.

position of the final lightweight samples (with microfibers reinforcement) is shown in Table 3.

\section{EXPERIMENTAL METHODS}

The dynamic modulus of elasticity was measured for all non-lightened samples. The resonance method was used to measure the dynamic modulus of elasticity. Because it is a non-destructive method, measurement was repeat in different times $(1,7,14,21$ and 28 days). The method is based on the measurement of fundamental resonant frequencies of transverse, longitudinal and torsional oscillations. The dynamic modulus of elasticity was measured by Brüel \& Kjær measuring set. The measuring set contains a Brüel \& Kjær impact hammer type 8206, a Brüel \& Kjær acceleration sensor type 4519-003, a Brüel \& Kjær Fron-end 3560B-120 measuring control panel and a control unit. The test specimens were placed on one support in the middle when measuring longitudinal or torsional oscillations; when measuring the transverse oscillation, the samples were placed on two supports at the prescribed distances (Figure 2).

The response sensor $(\mathrm{S}$ ) was glued to the prescribed position, subsequently the oscillation was excited by the impact of the impact hammer (B - exciter). The measurement was recorded by measuring control unit and then the resonant frequency for each oscillation was determined using PULSE LabShop software version 14.0.1. Finally, the fundamental resonant frequencies were determined and dynamic modulus of elasticity and shear modulus were calculated.

Destructive measurement was performed on laboratory samples $40 \times 40 \times 160 \mathrm{~mm}$. Each set of samples

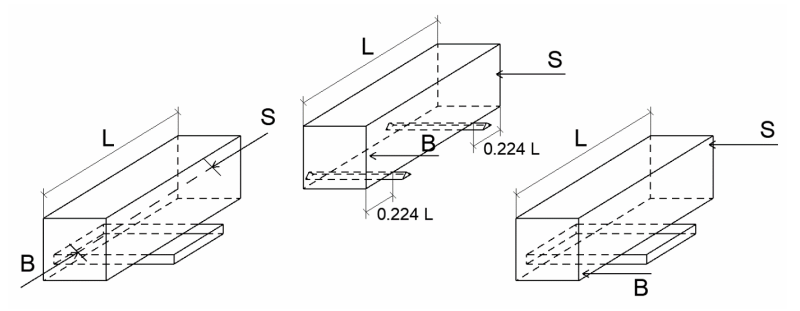

FiguRE 2. Diagram of the sensor location (S) and hammer impact point (B) when measuring longitudinal (left), transverse (middle), and torsional (right) oscillations using the resonance method [10].

contained 6 test specimens. Samples were stored for 28 days into water basin in a laboratory environment at $22 \pm 1^{\circ} \mathrm{C}$. First, three-point bending tests were performed using a hydraulic press, during which the test specimens were halved. Then compressive tests were performed on the halves of the test specimens (approximately $40 \times 40 \times 80 \mathrm{~mm}$ ) using a hydraulic press.

\section{Results And Discussion}

To select the optimal composition of the cement composite material, the individual components were first selected during testing on non-light samples, then the components were applied to a lightweight matrix. The polypropylene fibers were modified by oxygen plasma. The plasma modification of the fiber surface has a positive effect on the mechanical properties of the tested cementitious composite containing micronized recyclate. During plasma modification process the fibers lose almost no weight, which proves 


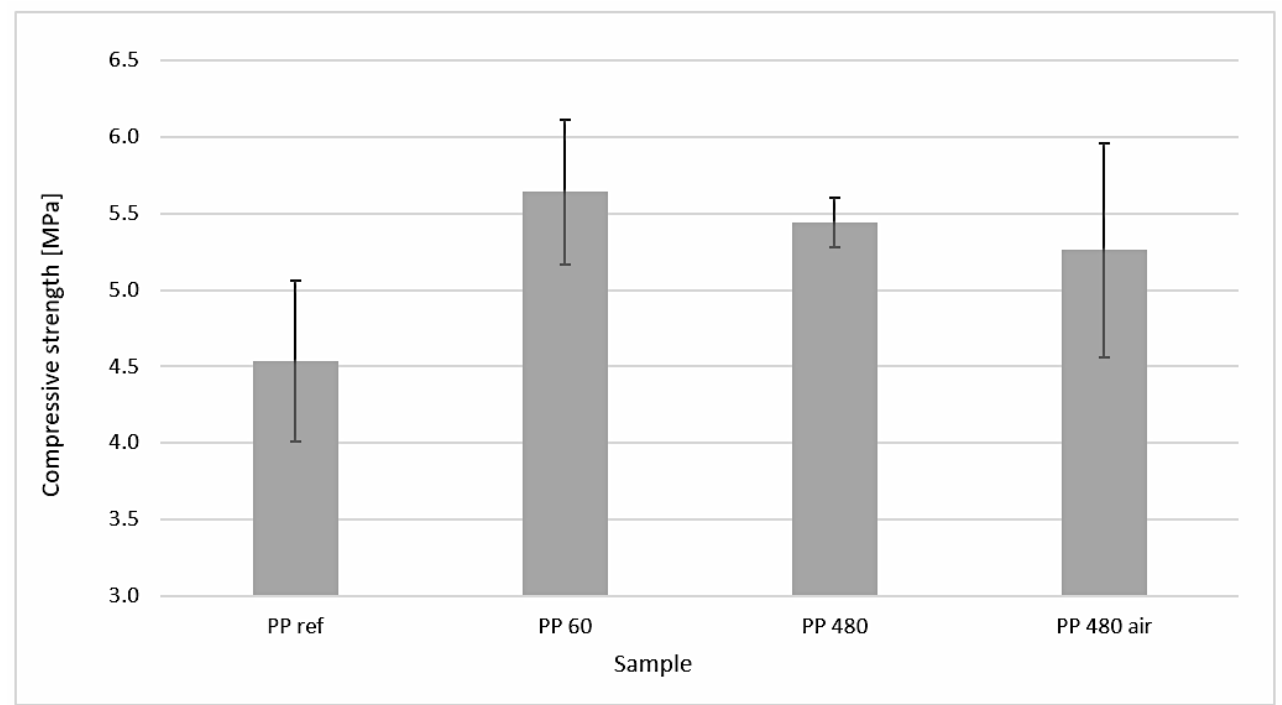

FiguRE 3. Flexural strength of samples containing fibers with different plasma modification times.

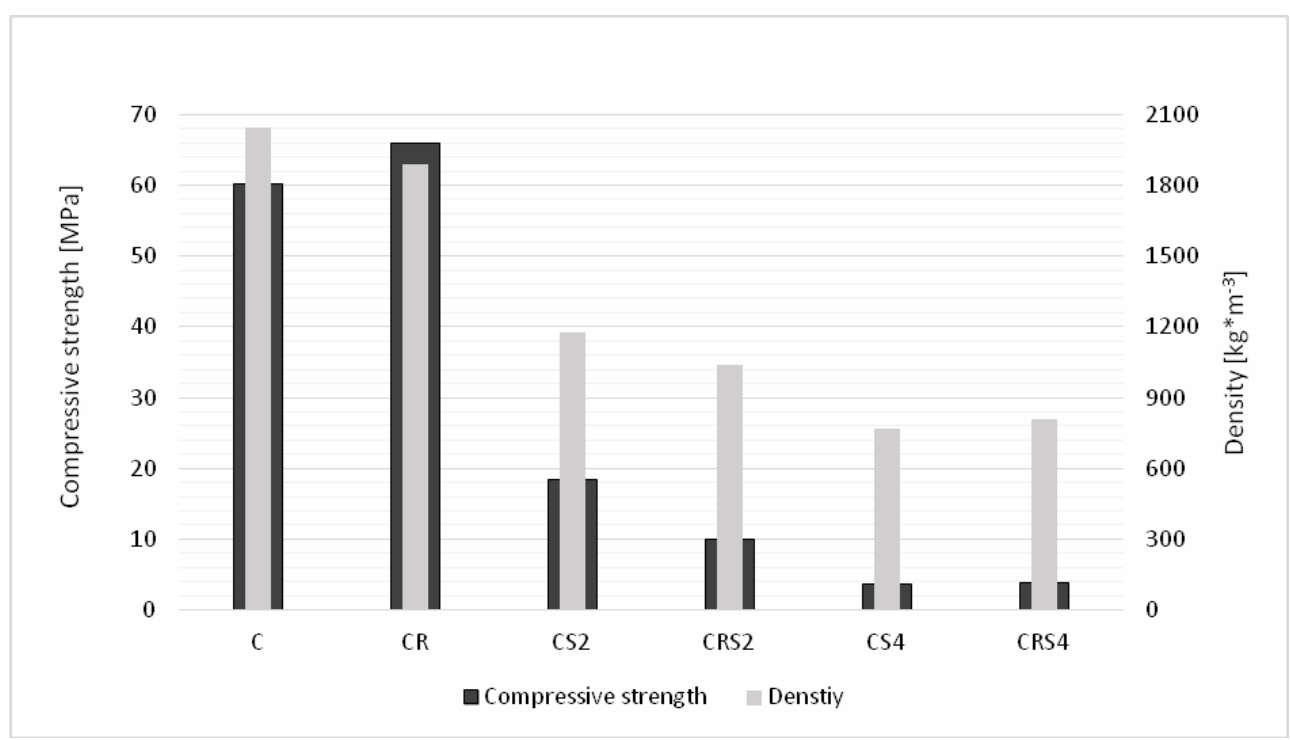

FiguRE 4. Compressive strength and density of samples with different amount of foaming agent.

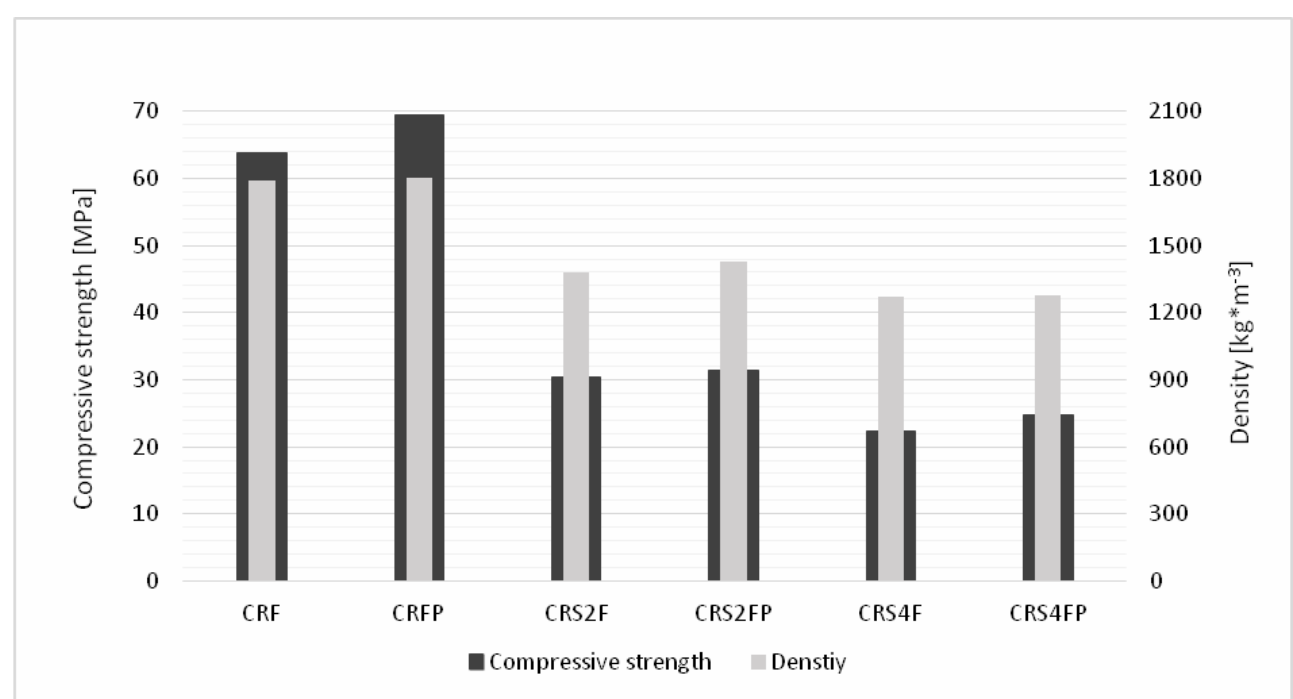

FiguRE 5. Compressive strength and density of lightweight cementitious composites containing recycled concrete reinforced by plasma modified fibers. 
that the diameter of the fibers is almost not reduced and mechanical properties of fibers are approximately the same as before the modification. When examining the surface of the fibers by SEM, the mechanical effect of the plasma modification on the surface was noticeable only for the fibers that were modified for 240 seconds or more. The mechanical properties of the test specimens were best for samples containing fibers modified with oxygen plasma for 60 seconds, with longer modification times the mechanical properties were no longer improving (Figure 3). Oxygen plasma modification for 60 seconds was chosen as the optimal modification for polypropylene microfibers.

The optimal amount of recycled concrete was chosen based on previous experiments $[11,12]$. The ratio between cement and micronized concrete recycled was determined to $1: 1$.

A total of six different foaming agents were tested to lighten the samples. The best results for lightening the cement matrix containing micronized recycled concrete were achieved by the foaming agent Sika Lightcrete 400. The most lightened samples had a bulk density about $800 \mathrm{~kg} \cdot \mathrm{m}^{-3}$ and a compressive strength about $4 \mathrm{MPa}$ (Figure 4).

Finally, lightweight samples reinforced with plasma-modified fibrous reinforcement were tested. The amount of fibers was chosen based on the recommended dosage from the manufacturer, the samples contained one $\mathrm{kg}$ of fibers per $\mathrm{m} 3$ of cement composite. At the recommended amount of fibers, samples containing plasma-modified microfibers achieved almost the same flexural strengths as samples containing fibers without plasma modification. Samples containing plasma modified fibers achieved slightly higher compressive strengths compared to samples without plasma modification. However, the increase in compressive strength was not very significant. The results are shown in Figure 5.

\section{Conclusion}

Plasma modification by oxygen plasma increases the cohesion of polypropylene microfibers with the cement matrix. The mechanical effect of plasma modification by oxygen plasma on the fiber surface is insufficient. When dosing micronized concrete recycled and cement into the matrix in a ratio of $1: 1$, good mechanical properties of the cement composite material are achieved. When the microfiber reinforcement was applied to the lightweight cementitious matrix, there was an increase in bulk density compared to the same lightweight material without fibrous reinforcement. The use of oxygen plasma to modify fibers surface and their application into a lightweight cement matrix does not have a significant effect on the mechanical properties of this lightweight material. In order to achieve better mechanical properties of this lightweight material, it is necessary to increase the amount of fibers and to choose another type of plasma modification. To achieve better mechanical properties of the reinforced lightweight cement matrix, it may be appropriate to modify fibers surface by argon plasma. The modification by argon plasma is expected to have a significantly higher mechanical effect on polypropylene fibers surface compared to the oxygen plasma modification.

\section{ACKNOWLEDGEMENTS}

This work was financially supported by the Czech Technical University in Prague - the project SGS19/148/OHK1/3T/11. The authors also thank to the Center for Nanotechnology in Civil Engineering at the Faculty of Civil Engineering, Czech Technical University in Prague.

\section{REFERENCES}

[1] A. Bentur, S. Mindess. Fibre reinforced cementitious composites. New York, 2007.

[2] J. P. Ollivier, J. C. Maso, B. Bourdette. transition zone in concrete. Advanced Cement Based Materials 2(1):30-38, 1995. DOI:10.1016/1065-7355(95)90037-3.

[3] M. M. Kabir, H. Wang, K. T. Lau, F. Cardona. Effects of chemical treatments on hemp fibre structure. Applied Surface Science 276:13-23, 2013. DOI:10.1016/j.apsusc.2013.02.086

[4] S. R. Sabreen. Cold Gas Plasma Surface Modification Ú Optimize Plastics Bonding Adhesion, 2012.

[5] J. Tinneke, M. Rino, N. Geyter, et al. Plasma surface modification of biomedical polymers: Influence on cell-material interaction. Plasma Chemistry and Plasma Processing 32:1039-1079, 2012. DOI:10.1007/s11090-012-9394-8.

[6] V. W. Y. Tam, C. M. Tam. A review on the viable technology for construction waste recycling. Resources, Conservation and Recycling 47(3):209-221, 2006. DOI:10.1016/j.resconrec.2005.12.002.

[7] I. Vegas, J. A. Ibanez, A. Lisabona, M. Cortazar, A. S. abd Frias. Pre-normative research on the use of mixed recycled aggregates in unbound road sections. Construction and Building Materials 25(5):2674-2682, 2011. DOI:10.1016/j.conbuildmat.2010.12.018.

[8] Z. Prošek, P. Tesárek, J. Trejbal. Recycling and its use in concrete waste processing by high-speed milling. Acta Polytechnica CTU Proceedings 21:28-32, 2019. DOI:10.14311/APP.2019.21.0028.

[9] K. Ramamurthy, E. K. Nambiar, G. I. S. Ranjani. A classification of studies on properties of foam concrete. Cement and Concrete Composites 31(6):388-396, 2009. DOI:10.1016/j.cemconcomp.2009.04.006.

[10] ČSN 731372 Nedestruktivní zkoušení betonu-Rezonačnní metoda zkoušení betonu, 2012.

[11] Z. Prošek, J. Trejbal, V. Nežerka, et al. Recovery of residual anhydrous clinker in finely ground recycled concrete. Resources, Conservation and Recycling 155, 2020 .

[12] Z. Prošek, J. Topič, J. Ďureje, J. Trejbal. Srovnání vlivu mikromletého betonu a mramorové moučky na mechanické vlastnosti cementových past. In Waste Forum 2:262-267, 2018. 